\title{
EFFECT OF HERBICIDE RESISTANCE ON SEED PHYSIOLOGY OF Phalaris MINOR (LITTLESEED CANARYGRASS)
}

\author{
Jesús R. Torres-García ${ }^{1,2}$, Ebandro Uscanga-Mortera ${ }^{1,4}$, Carlos Trejo ${ }^{1}$, Víctor Conde-Martínez ${ }^{1}$, \\ Josue Kohashi-Shibata ${ }^{1}$, Juan NúÑez-Farfán ${ }^{2}$ and David Martínez-Moreno ${ }^{3}$ \\ 'Postgrado en Botánica, Colegio de Postgraduados, Montecillo, Texcoco, Estado de México, Mexico \\ ${ }^{2}$ Laboratorio de Genética Ecológica y Evolución, Departamento de Ecología Evolutiva, Instituto de Ecología, \\ Universidad Nacional Autónoma de México, México, D.F., Mexico \\ ${ }^{3}$ Escuela de Biología, Benemérita Universidad Autónoma de Puebla, Puebla, Mexico \\ ${ }^{4}$ Corresponding author: euscanga@colpos.mx
}

\begin{abstract}
Herbicide resistance is an evolutionary process that may involve changes in physiological and ecological traits related to plant fitness. This type of resistance occurs in littleseed canarygrass (Phalaris minor). This study was aimed to determine the effect of resistance to ACCase-inhibiting herbicides on fitness of seed accessions of littleseed canarygrass. Seed characteristics are important because they may determine the outcome of competition between susceptible (S) and resistant (R) biotypes. Experiments were performed to determine whether differences between $\mathrm{S}$ and $\mathrm{R}$ accessions in embryo size, dormancy, longevity, and germination speed might occur. Differences in plant fitness associated to herbicide resistance were found in seed physiological characteristics. The embryo size of R accessions was reduced up to $50 \%$ (on a dry weight basis), which resulted in an increase in the number of days required to germinate and a reduction in the germination speed. Damage to membranes, which is related to longevity, was more severe in the R accessions. The observed decrease in seed vigor could affect the establishment of seedlings, which may explain the low success of $\mathrm{R}$ accessions under herbicide selection pressure.
\end{abstract}

Key words: ACCase-inhibiting herbicides, fitness, germination, dormancy, longevity, vigor.

Resumen: La resistencia a herbicidas es un proceso evolutivo que puede involucrar cambios en caracteres ecológicos y fisiológicos asociados con la adecuación de las plantas. Este tipo de resistencia ocurre en Phalaris minor. El objetivo de este estudio fue determinar el efecto de la resistencia a herbicidas inhibidores de la ACCasa en la aptitud de las semillas de Phalaris minor. Las características de las semillas son importantes debido a que la competencia entre biotipos susceptibles (S) y resistentes (R) inicia en esta etapa. Una serie de experimentos fueron realizados para determinar si existen diferencias entre colectas $\mathrm{S}$ y $\mathrm{R}$ en aspectos como el tamaño del embrión, latencia, longevidad y velocidad de germinación. Se encontraron diferencias en la aptitud asociadas con la resistencia a herbicidas, las cuales mostraron diferencias en la calidad fisiológica de las semillas. El tamaño del embrión de las colectas R se redujo en un 50 \% (con base en la materia seca), lo cual ocasionó un incremento en el número de días a la germinación y la reducción de la velocidad de germinación. El daño en las membranas, que fue usado como una medida para indicar la longevidad, fue más severo en las colectas R. La reducción observada en el vigor de las semillas podría afectar el establecimiento de las plántulas, y podría dar una explicación del bajo establecimiento de las colectas R cuando la presión de selección del herbicida está ausente.

Palabras clave: aptitud, germinación, herbicidas inhibidores de la ACCasa, latencia, longevidad, vigor.

$\mathbf{W}_{\mathrm{r}}$ eeds have been intensively selected by the cultural practices used to eliminate them. Herbicide-resistant biotypes represent one example of this human-imposed selection (Christoffers, 1999; Baucom and Holt, 2009; Neve et al., 2009). When weeds are controlled by chemical methods (herbicides), an intense selection pressure is imposed.
Such selection pressure can eliminate $99.99 \%$ of individuals. However, if a few individuals survive to herbicide application, the population will change the population phenotypic and genotypic proportions to completely resistant individuals in some generations (Maxwell et al., 1990). Thus far, 348 biotypes of 194 species have shown herbi- 
cide resistance, and further increase in these numbers is expected despite the introduction of new chemical compounds (Coustau et al., 2000; Heap, 2013). Agricultural practices that include herbicide application will inevitably lead to the development of resistance, even when the herbicide is used at low doses (Neve and Powles, 2005a, b).

Herbicide resistance may involve an ecological cost related to competitive ability (fitness). Such costs can be evaluated physiologically, genetically, and evolutionarily to generate models that can aid their management (Coustau et al., 2000; Neve et al., 2009). The model of Maxwell et al. (1990) predicts the evolution of resistance and a return to susceptibility when herbicide application is stopped. However, this model is entirely theoretical and depends on a reduction in the competitive ability of plants.

Phalaris minor Retz. (litltleseed canarygrass), a weed native to Asia has invaded wheat fields in 60 countries (Afentouli and Eleftherohorinos, 1996; Iqbal and Wright, 1997; Hari et al., 2003; Chhokar and Sharma, 2008). This weed has evolved resistance to many herbicides with different mode of action (ALS, ACCase and PSII inhibitors). In Mexico, 5,000 ha (100 to 500 farms) from the Bajio agricultural area are infested with $P$. minor resistant to lipid inhibitors herbicides, specifically to ACCase inhibitors (Heap, 2013); nevertheless, studies have focused only in detecting herbicide-resistant biotypes. Seeds of $P$. minor susceptible to ACCase inhibitors remain viable ca. two years under field conditions and require a period of cold to break dormancy. Under natural conditions, the seeds reach their highest germination percentage at 70 days after dispersal (Om et al., 2005). However, excess of soil humidity decreases their vigor and longevity, depending on their depth in the soil (Franke et al., 2007).

Differences in seed characteristics determine seed persistence of resistant $(\mathrm{R})$ biotypes in the soil seed bank (Ghersa and Martínez-Ghersa, 2000). Moreover, fitness differences between susceptible and resistant seeds could determine the ability to invade natural habitats and be a problem for native flora. The size of the embryo, dormancy, longevity, and germination speed are measures of seed vigor that may determine plant establishment under non-selective conditions (Weaver and Thomas, 1986; Winn, 1988; Alcocer-Ruthling et al., 1992; Dyer et al., 1993; Thompson et al., 1994). Empirical evidence shows that resistance to ACCase inhibitors in grasses involves fitness costs in terms of a reduction in longevity, germination percentage, and vigor (Ghersa and Martínez-Ghersa, 2000; Vila-Aiub et al., 2005a, b; Gundel et al., 2008). However, no studies have addressed the potential herbicide resistance costs in seeds of Phalaris minor. This study attempted to determine the fitness differences between susceptible (S) and resistant (R) accessions of $P$. minor in seed physiology (biomass allocation, dormancy, longevity, and germination).

\section{Materials and method}

A collection of at least 20 populations reported as resistant to diclofop were performed in Bajio, Mexico $\left(20^{\circ} 25^{\prime} \mathrm{N} 101^{\circ}\right.$ $38^{\prime} \mathrm{W}$ ). The resistance index (RI) of each accession was determined using the method proposed by Tal et al. (2000). The results showed that four of these accessions had a RI to diclofop that was higher than seven with respect to the $\mathrm{S}$ line. Additionally, gene-sequencing studies showed that the resistance mutations at the site of action occurred in different locations; thus, we established that each accession had a different evolutionary origin (research in progress). Finally, four accessions were selected: $\mathrm{Col} 4, \mathrm{Col}$ 7, Gto, and Jal. The $\mathrm{S}$ accession was collected from an area located at 25 $\mathrm{km}$ from the area where $\mathrm{R}$ accessions were collected and where herbicides are not applied for weed control (personal communication with farmers).

To ensure that the seeds used in this study corresponded only to R individuals, selection for resistance was performed. Seeds of each accession were placed in agar with an herbicide concentration of $40 \mathrm{mg} \mathrm{L}^{-1}$ (approximately 8X greater than the concentration at which $\mathrm{S}$ plants can grow). The seeds that germinated were sown in plastic pots filled with soil, and the plants were maintained in a greenhouse. At flowering, the spikes were covered with waxed paper bags to avoid cross-pollination, and the seeds were collected as they were released (at maturity). This procedure was performed to eliminate differences in secondary dormancy and aging due to storage. The obtained seeds were kept in paper bags at $18{ }^{\circ} \mathrm{C}$ until use.

Allocation of biomass to seed parts. Thirty florets with similar weights $(1.8 \mathrm{mg})$ were selected for each accession. The florets were dissected into floral sheaths, endosperm, and embryo. Each part was dried in an oven at $80{ }^{\circ} \mathrm{C}$ for $72 \mathrm{~h}$.

Breaking dormancy. Species of the genus Phalaris require periods of low temperature to break seed dormancy (Om et al., 2005). To determine whether each accession requires different conditions to break dormancy, batches of 100 seeds were stratified at $5{ }^{\circ} \mathrm{C}$ for 10,20 , and 30 days. The control batch was not stratified. After stratification, the seeds were germinated $\left(16^{\circ} \mathrm{C} ; 12 \mathrm{~h}\right.$ photoperiod) to observe whether stratification was able to break the dormancy. Germination was measured by evaluating the number of germinated seeds at intervals of 5 days over a period of 60 days. The viability of ungerminated seeds was determined by the tetrazolium chloride test $(1 \%)$. The number of days to germination (NDG; Hartmann et al., 1993) and the germination speed (GS; Maguire, 1962) were calculated as follows:

$$
\begin{gathered}
\mathrm{NDG}=\left(\left(\mathrm{N}_{1} \times \mathrm{T}_{1}+\mathrm{N}_{2} \times \mathrm{T}_{2}+\ldots .+\mathrm{N}_{\mathrm{n}} \times \mathrm{T}_{\mathrm{n}}\right) /\right. \\
\text { Total number of germinated seed }) \\
\mathrm{GS}=\left(\mathrm{N}_{1}+\mathrm{N}_{2}+\ldots .+\mathrm{N}_{\mathrm{n}}\right) / \\
\text { Time from the sowing to the final count })
\end{gathered}
$$


Where:

$\mathrm{N}=$ number of seeds germinated within consecutive time intervals

$\mathrm{T}=$ time between the start of the test and the end of the interval

Longevity estimated by accelerated aging. The Jal accession was not included in this experiment because there was not enough seed available. The accelerated aging test (Gundel et al., 2008; ISTA, 2009) was performed by placing 100 seeds of each accession in aging chambers at $45{ }^{\circ} \mathrm{C}$ with $100 \%$ relative humidity $(\mathrm{RH})$ for $0,24,48,72$, and $96 \mathrm{~h}$, resulting in 20 treatments (4 accessions, 5 durations). The electrical conductivity (EC, $\mathrm{dS} \mathrm{m} \mathrm{m}^{-1}$ ) was measured to estimate damage to the cell membranes caused by the accelerated aging test.

Statistical analysis. Prior to the statistical analysis, the proportions of allocation of biomass were arcsine transformed. The experimental data were analyzed using ANOVA with the statistical package SAS ver. 9.1 (SAS, 2009). Four replicates with 25 seeds each were used in all treatments. In breaking dormancy time and longevity tests, data were analyzed using a completely randomized design with a factorial arrangement; the main factors were the accessions and stratification time or accelerated aging, respectively. Significant differences between treatment means were calculated with Tukey honestly significant difference (HSD) test with $P<0.05$.

\section{Results}

Allocation of biomass to seed parts. The endosperm was the structure with the highest biomass allocation, followed by the floral sheaths (lemma and palea) and the embryo (Table 1). Significant differences $(P<0.05)$ were observed in the weight and percentage of the seed occupied by the endosperm and embryo among the accessions. The accessions Gto and Jal had the lowest allocation percentage to the embryo which was compensated for an increase in the endosperm size. The $\mathrm{Col} 4, \mathrm{Col} 7$, and $\mathrm{S}$ accessions had an equal distribution of organic matter in the endosperm and embryo (Table 1).

Breaking dormancy. The seed dormancy of Phalaris minor was significantly different depending on the accession and the stratification time. However, significant differences were not found among the 10, 20, and 30 days stratification times. After stratification, the $\mathrm{S}$ accession had the highest germination percentage and speed compared with the $\mathrm{R}$ accessions (Figure 1A-E). Stratification increased the germination speed in $\mathrm{S}, \mathrm{Col} 4$, and Gto compared with no stratification; however, no differences were found among the 10, 20, and 30 days stratification times (Figure 1B, D).

Stratification did not improve the germination percentage and speed of Col 7 and Jal, and the latter exhibited the lowest germination percentage (Figure 1C, E). However, this result occurred because the treatments failed to break dormancy as the tetrazolium chloride test showed that all seeds were viable at the time of the experiment.

Significant differences in the NDG and the GS were found between both the accessions and stratification times (Table 2). The $\mathrm{S}$ accession required less time to germinate (16.7 days) and had the highest GS (38.1). Among the $\mathrm{R}$ accessions, Jal required more days to germinate ( 44.4 days) and had the lowest GS (1.6).

Longevity estimated by accelerated aging. At the beginning of the experiment, all accessions showed the same EC (Table 3); however, as the aging time increased, the EC of all the accessions also increased. For the measurements performed at 24 and $48 \mathrm{~h}$, the $\mathrm{S}$ accession presented the lowest damage compared with the $\mathrm{R}$ accessions. However, this trend changed at 72 and $96 \mathrm{~h}$, when the $\mathrm{S}$ accession had the highest EC values. The generalized deterioration of all accessions was obvious at $96 \mathrm{~h}$, with the release of the glumes and endosperm degradation. Higher EC is an indirect measurement of membrane damage, and a lower EC indicates greater cell membrane integrity. In nature, this value may suggest that the seeds with a lower EC will remain viable for a longer period in the soil bank compared with those with

Table 1. Dry matter weight and percentage biomass allocation to different structures of littleseed canarygrass (Phalaris minor) seeds that were susceptible and resistant (Col 4, Col 7, Gto, and Jal) to ACCase inhibitor herbicides. Different letters within columns indicate significant differences (Tukey, $P<0.05)$. The data are presented as the means \pm standard error.

\begin{tabular}{lcccccc}
\hline Accession & Glumes & $\begin{array}{c}\text { Endosperm } \\
\mathrm{mg}\end{array}$ & Embryo & Glumes & $\begin{array}{c}\text { Endosperm } \\
\%\end{array}$ & Embryo \\
\hline Susceptible & $0.35^{\mathrm{a}} \pm 0.02$ & $1.20^{\mathrm{ab}} \pm 0.02$ & $0.25^{\mathrm{a}} \pm 0.02$ & $19.5^{\mathrm{a}} \pm 0.93$ & $66.6^{\mathrm{b}} \pm 1.2$ & $13.9^{\mathrm{a}} \pm 0.9$ \\
Col 4 & $0.36^{\mathrm{a}} \pm 0.02$ & $1.18^{\mathrm{b}} \pm 0.02$ & $0.26^{\mathrm{a}} \pm 0.03$ & $20.0^{\mathrm{a}} \pm 0.91$ & $65.6^{\mathrm{b}} \pm 1.4$ & $14.4^{\mathrm{a}} \pm 1.9$ \\
Col 7 & $0.40^{\mathrm{a}} \pm 0.02$ & $1.18^{\mathrm{b}} \pm 0.03$ & $0.22^{\mathrm{ab}} \pm 0.03$ & $22.2^{\mathrm{a}} \pm 0.01$ & $65.6^{\mathrm{b}} \pm 1.6$ & $12.2^{\mathrm{ab} \pm 1.6}$ \\
Gto & $0.38^{\mathrm{a}} \pm 0.02$ & $1.28^{\mathrm{a}} \pm 0.02$ & $0.14^{\mathrm{b}} \pm 0.02$ & $21.6^{\mathrm{a}} \pm 1.0$ & $71.1^{\mathrm{a}} \pm 1.1$ & $7.3^{\mathrm{b}} \pm 1.2$ \\
Jal & $0.39^{\mathrm{a}} \pm 0.02$ & $1.28^{\mathrm{a}} \pm 0.02$ & $0.13^{\mathrm{b}} \pm 0.02$ & $21.7^{\mathrm{a}} \pm 1.0$ & $71.1^{\mathrm{a}} \pm 1.1$ & $7.2^{\mathrm{b}} \pm 1.2$ \\
\hline
\end{tabular}



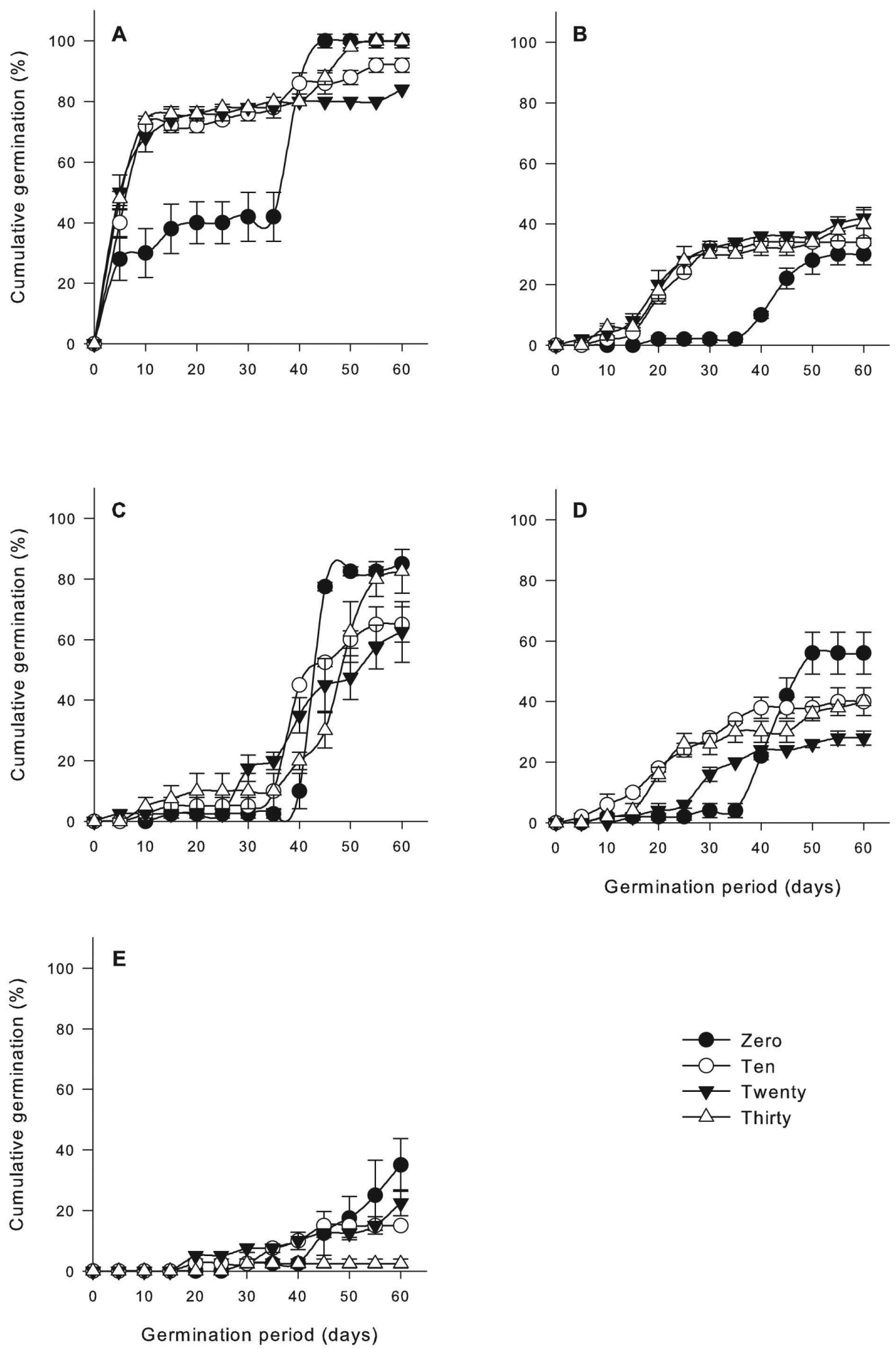

Figure 1. Dynamics of seed germination (\%) after breaking dormancy in a susceptible accession (A) and the herbicide-resistant accessions Col 4 (B), Col 7 (C), Gto (D), and Jal (E) of littleseed canarygrass (Phalaris minor). The treatments used to break dormancy were 0, 10, 20 , and $30 \mathrm{~d}$ at $5{ }^{\circ} \mathrm{C}$. The results are presented as the mean \pm standard error. 
Table 2. Number of days to germination (NDG) and germination speed (GS) after stratification $\left(0,10,20\right.$, or 30 days at $5{ }^{\circ} \mathrm{C}$ ) of littleseed canarygrass (Phalaris minor) seeds that were susceptible and resistant (Col 4, Col 7, Gto and Jal) to ACCase inhibitor herbicides. $*, * *$, and $* * *$ indicate $0.05,0.001$ and 0.0001 levels of probability (Tukey, $P<0.05$ ), respectively. Different letters within columns indicate significant differences (Tukey, $P<0.05$ ). The data are presented as the means \pm standard error.

\begin{tabular}{cccc}
\hline FACTORS & LEVELS & NDG & GS \\
\hline Accessions & Susceptible & $16.7^{\mathrm{c}} \pm 2$ & $38.1^{\mathrm{a}} \pm 2.0$ \\
& Col 4 & $30.5^{\mathrm{b}} \pm 2$ & $7.0^{\mathrm{b}} \pm 0.7$ \\
& Col 7 & $42.3^{\mathrm{a}} \pm 1$ & $7.6^{\mathrm{b}} \pm 0.7$ \\
& Gto & $32.7^{\mathrm{b}} \pm 2$ & $6.6^{\mathrm{b}} \pm 0.6$ \\
& Jal & $44.4^{\mathrm{a}} \pm 3$ & $1.6^{\mathrm{c}} \pm 0.3$ \\
\hline Stratification time & 0 & $42.4^{\mathrm{a}} \pm 2$ & $8.8^{\mathrm{b}} \pm 2$ \\
& 10 & $27.8^{\mathrm{c}} \pm 2$ & $13.3^{\mathrm{a}} \pm 3$ \\
& 20 & $30.8^{\mathrm{bc}} \pm 2$ & $13.0^{\mathrm{a}} \pm 3$ \\
& 30 & $32.3^{\mathrm{b}} \pm 3$ & $13.7^{\mathrm{a}} \pm 3$ \\
\hline \multirow{2}{*}{ Interactions } & Accessions & $* * *$ & $* * *$ \\
& Time & $* * *$ & $* * *$ \\
& Accessions $\times$ Time & $*$ & $* * *$ \\
\hline
\end{tabular}

a higher EC. Hereafter, these data will be considered to be longevity data.

\section{Discussion}

Differences associated with resistance to ACCase-inhibiting herbicides were found in the physiology and morphology of Phalaris minor seeds. The evaluated variables, including the allocation of dry matter, dormancy, and longevity revealed fitness differences in all resistant accessions. Similar results were obtained by Gundel et al. (2008) and Vila-Aiub et al. (2005b) for seeds of the biotypes Lolium multiflorum and $L$. rigidum, respectively, which were resistant to ACCase inhibitors.

The seeds of Gto and Jal showed a $50 \%$ reduction in the size of the embryo, a deeper dormancy and a decreased longevity compared with the $\mathrm{S}$ accession. López-Castañeda et al. (1996) found differences in the initial vigor of cereals such as oat, sorghum, wheat, and triticale directly related to the size of the embryo. So far, no studies have previously correlated embryo size with dormancy and longevity in herbicide-resistant accessions. However, Forbis et al. (2002) indicated that the embryo size may be related to the primary dormancy of seeds. Plants that produce seeds with small embryos must go through a maturation period that may take several months (morpho-physiological dormancy); in addition, they lack the necessary vigor to break seeds sheaths (morphological dormancy). These facts provide advantages to $\mathrm{S}$ accessions over $\mathrm{R}$ accessions.

The reduction in the proportion of biomass allocated to the embryo in the seeds of $\mathrm{R}$ accessions caused increase in
Table 3. Longevity of littleseed canarygrass (Phalaris minor) seeds that were susceptible and resistant ( $\mathrm{Col} 4, \mathrm{Col} 7$, Gto and Jal) to ACCase inhibitor herbicides. Longevity was measured by electrical conductivity $\left(\mathrm{dS} \mathrm{m}^{-1}\right)$ after $0,24,48,72$, and $96 \mathrm{~h}$ of accelerated aging $\left(45^{\circ} \mathrm{C}\right.$ and $100 \% \mathrm{RH}$ ). Different letters within columns indicate significant differences (Tukey, $P<0.05$ ). The data are presented as the means \pm standard error.

\begin{tabular}{cccccc}
\hline Accessions & $\mathbf{5}$ & $\mathbf{2 4}$ & $\begin{array}{c}\text { Hours } \\
\mathbf{4 8} \\
\mathbf{d S} \mathbf{~ m}^{-1}\end{array}$ & $\mathbf{7 2}$ & $\mathbf{9 6}$ \\
\hline Susceptible & $0.5^{\mathrm{a}} \pm 0.01$ & $0.7^{\mathrm{c}} \pm 0.06$ & $1.0^{\mathrm{d}} \pm 0.01$ & $3.8^{\mathrm{a}} \pm 0.2$ & $36^{\mathrm{a}} \pm 0.6$ \\
Col 4 & $0.5^{\mathrm{a}} \pm 0.01$ & $1.6^{\mathrm{a}} \pm 0.03$ & $1.2^{\mathrm{c}} \pm 0.01$ & $2.0^{\mathrm{b}} \pm 0.1$ & $30^{\mathrm{ab}} \pm 0.6$ \\
Col 7 & $0.5^{\mathrm{a}} \pm 0.01$ & $1.2^{\mathrm{b}} \pm 0.09$ & $1.6^{\mathrm{a}} \pm 0.06$ & $1.6^{\mathrm{b}} \pm 0.1$ & $23^{\mathrm{b}} \pm 4.7$ \\
Gto & $0.5^{\mathrm{a}} \pm 0.01$ & $2.2^{\mathrm{a}} \pm 0.03$ & $1.5^{\mathrm{b}} \pm 0.03$ & $2.0^{\mathrm{b}} \pm 0.1$ & $20^{\mathrm{b}} \pm 0.1$ \\
\hline
\end{tabular}

the NDG and led to reduce germination speed. In the case of $\mathrm{S}$ and Col 4, which had the largest embryos, the NDG was decreased considerably. The accessions with a small embryo size had low germination speed. The accessions Gto and Jal had the lowest germination ability, consistent with the low proportion of biomass allocated to the embryo. One of the consequences of the intense selection pressure exerted by xenobiotics is the increase in inbreeding as a result of the bottleneck that occurs in populations. Inbreeding in turn may reduce vigor of individuals due to low genetic variability. However, studies addressing seeking the relationship between the genetic diversity of populations and the loss of fitness in herbicide resistant weeds, as the accessions studied here, are urgently needed (research in progress).

Besides the proportion of biomass allocated to the embryo within the seed, there are other factors that may explain the differences in the dormancy and longevity of the seeds. The $\mathrm{R}$ accessions $\mathrm{Col} 4$ and $\mathrm{Col} 7$, which had embryos that were relatively similar to those of the $\mathrm{S}$ accession, also displayed deep dormancy and decreased longevity. These differences may be due to other types of physiological costs; the pleiotropic effects that occur due to nucleotide changes may cause proteins to assume different morphologies and functions. In this respect, Menchari et al. (2008) found that point mutations in the genes responsible for resistance to ACCase inhibitors may affect the fitness (biomass accumulation and seed production) in populations of Alopecurus myosuroides.

The decrease in the embryo size observed in some R accessions could be the result of an antagonistic correlation between characteristics that compensate for survival in a highly selective $(99.9 \%)$ environment with losses in the biological aptitude (fitness). This type of "trade-off" has been observed when resistance to other selection agents is gained, such as resistance to herbivores and pathogens. The cost of resistance in terms of competitive ability in plants is more severe in the case of herbicides versus herbivory and pathogens based on the intensity of herbicide selection pressure (Bergelson and Purrington, 1996). 
The delay in the NDG and the germination speed of the R accessions might constitute an ecological disadvantage for $\mathrm{R}$ plants compared with S plants. During the growing season, when the conditions are suitable for germination, the seeds of $\mathrm{S}$ biotypes will be ready to germinate and occupy space, whereas the $\mathrm{R}$ biotypes will germinate later.

These late-emerging $\mathrm{R}$ plants will be shaded by the $\mathrm{S}$ plants and will not complete their life cycle (Vila-Aiub et al., 2005b). Mortimer (1997) indicated that one of the evolutionary responses used to avoid selection pressure from herbicides is the selection of individuals with deep dormancy; individuals that germinate later are more likely to complete their life cycle compared with those that have received herbicide application. Thus, with the disappearance of the selective factor, delayed germination may represent a disadvantage for the establishment of seedlings, which could cause the elimination of $\mathrm{R}$ plants and thus return of the population to the S state (Maxwell et al., 1990). Competition experiments between $\mathrm{R}$ and $\mathrm{S}$ accessions of Phalaris minor, shows that the $\mathrm{S}$ biotype germinates first and produced a larger canopy (data not shown).

The longevity (estimated by the accelerating aging test) is an indication of vigor, and it is also related to the size of the embryo. The seeds of $\mathrm{S}$ accessions, which presented the largest embryos, will be more tolerant to deterioration under natural conditions and will be viable for a longer time in the seed bank. In this regard, Gundel et al. (2008) reported that the longevity of Lolium multiflorum seeds is reduced because of herbicide resistance which causes a disadvantage under non-selective conditions.

The Jal seed accession was not subjected to this test because the plants produced a low number of seeds. In addition, the seeds had low quality. The reduction in competitive ability observed in this study could be the cause of the low success rate observed among $\mathrm{R}$ accessions under non-selective conditions, which could lead to restoration of susceptibility in these populations (Maxwell et al., 1990).

Given that agricultural practices that each farmer applies to their plot convert each accession into individual populations (Linhart and Grant, 1996), some studies have questioned the comparison of competitive ability among populations that do not share the same selection history (Neve, 2007; Vila-Aiub et al., 2009). However, it is interesting to note that the differences in the physiological quality of seeds from geographically isolated populations studied here, exhibited similar trends in all cases. The losses in fitness documented in this study may be the consequence of the evolution of resistance and may be found in all $\mathrm{R}$ accessions.

\section{Acknowledgments}

The first author is grateful to CONACyT for a Ph.D. fellowship. The authors thank Petra Yañez Jiménez and Antonio García Esteva for assistance with all phases of the research and J. Antonio Tafoya-Razo, who supplied the original seed used in this research. Also, to the annonimous reviewers for the observations and improvement of this paper.

\section{Literature cited}

Afentouli C.G. and Eleftherohorinos I.G. 1996. Littleseed canarygrass (Phalaris minor) and short-spiked canarygrass (Phalaris brachystachys) interference in wheat and barley. Weed Science 44:560-565.

Alcocer-Ruthling M., Thill D.C. and Shafii B. 1992. Seed biology of sulfonylurea - resistant and - susceptible biotypes of prickly lettuce (Lactuca serriola). Weed Technology 6:858-864.

Baucom R.S. and Holt J.S. 2009. Weeds of agricultural importance: bridging the gap between evolutionary ecology and crop and weed science. New Phytologist 184:741-743.

Bergelson J. and Purrington C.B. 1996. Surveying patterns in the cost of resistance in plants. The American Naturalist 148:536558.

Chhokar R.S. and Sharma R.K. 2008. Multiple herbicide resistance in littleseed canarygrass (Phalaris minor): A threat to wheat production in India. Weed Biology and Management 8:112-123.

Christoffers M.J. 1999. Genetic aspects of herbicide-resistant weed management. Weed Technology 13:647-652.

Coustau C., Chevillon C. and French-Constant R. 2000. Resistance to xenobiotics and parasites: can we count the cost? Trends in Ecology \& Evolution 15:378-383.

Dyer W.E., Chee P.W. and Fay P.K. 1993. Rapid germination of sulfonylurea-resistant Kochia scoparia L. accessions is associated with elevated seed levels of branched chain amino acids. Weed Science 41:18-22.

Forbis T.A., Floyd S.K. and Queiroz A. de. 2002. The evolution of embryo size in angiosperms and other seed plants: implications for the evolution of seed dormancy. Evolution 56:2112-2125.

Franke A.C., Singh S., MacRoberts N., Nehra A.S., Godara S., Malik R.K. and Marshall G. 2007. Phalaris minor seedbank studies: longevity, seedling emergence and seed production as affected by tillage regime. Weed Research 47:73-83.

Ghersa C.M. and Martínez-Ghersa M.A. 2000. Ecological correlates of weed seed size and persistence in the soil under different tilling systems: implications for weed management. Field Crops Research 67:141-148.

Gundel P.E., Martínez-Ghersa M.A. and Ghersa C.M. 2008. Dormancy, germination and ageing of Lolium multiflorum seeds following contrasting herbicide selection regimes. European Journal of Agronomy 28:606-613.

Hari O.M., Dhiman S.D., Hemant K., and Sajjan K. 2003. Biology and management of Phalaris minor in wheat under a rice/wheat system. Weed Research 43:59-67.

Hartmann H., Kester E. and Davies F. 1993. Plant propagation: Principles and practices. Prentice-Hall. New Delhi.

Heap I. 2013. International survey of herbicide resistant weeds. <http://www.weedscience.org> (accesed 07 july 2013).

Iqbal J. and Wright D. 1997. Effects of nitrogen supply on competition between wheat and three annual weed species. Weed Research 37:391-400.

International Seed Testing Association. ISTA. 2009. International Rules for Seed Testing 2009. Bassersdorf.

Linhart B.Y. and Grant C.M. 1996. Evolutionary significance of 
local genetic differentiation in plants. Annual Review of Ecology Systematics 27:237-277.

López-Castañeda C., Richards R.A., Farquhar G.D. and Williamson R.E. 1996. Seed and seedling characteristics contributing to variation in early vigor among temperate cereals. Crop Science 36:1257-1266.

Maguire J.D. 1962. Speed of germination - aid in selection and evolution for seedling emergence and vigor. Crop Science 2:176-177.

Maxwell B.D., Roush M.L. and Radosevich S.R. 1990. Predicting the evolution and dynamics of herbicide resistance in weed populations. Weed Technology 4:2-13.

Menchari Y., Chauvel B., Darmency H. and Délye C. 2008. Fitness costs associated with three mutant acetyl-coenzyme A carboxylase alleles endowing herbicide resistance in black-grass Alopecurus myosuroides. Journal of Applied Ecology 45:939-947.

Mortimer A.M. 1997. Phenological adaptation in weeds-an evolutionary response to the use of herbicides? Pesticide Science 51:299-304.

Neve P. 2007. Challenges for herbicide resistance evolution and management: 50 years after Harper. Weed Research 47:365369.

Neve P. and Powles S. 2005a. High survival frequencies at low herbicide use rates in populations of Lolium rigidum result in rapid evolution of herbicide resistance. Heredity 95:485-492.

Neve P. and Powles S. 2005b. Recurrent selection with reduced herbicide rates result in the rapid evolution of herbicide resistance in Lolium rigidum. Theoretical Applied Genetics 110:1154-1166.

Neve P., Vila-Aiub M. and Roux F. 2009. Evolutionary-thinking in agricultural weed management. New Phytologist 184:783-793.

Om H., Kumar S. and Dhiman S.D. 2005. Dormancy and viability of Phalaris minor seed in a rice-wheat cropping system. Weed Research 45:140-148.

SAS. Statistical Analysis System. 2009. SAS/STAT User's guide. SAS Institute Inc., Cary.

Tal A., Kotoula-Syka E. and Rubin B. 2000. Seed-bioassay to detect grass weeds resistant to acetyl coenzyme A carboxylase inhibiting herbicides. Crop Protection 19:467-472.

Thompson C.R., Thill C.D. and Shafii B. 1994. Germination characteristics of sulfonylurea - resistant and - susceptible Kochia (Kochia scoparia). Weed Science 42:50-56.

Vila-Aiub M.M., Neve P. and Powles S.B. 2005a. Resistance cost of a cytochrome $\mathrm{P} 450$ herbicide metabolism mechanism but not an ACCase target site mutation in a multiple resistant Lolium rigidum population. New Phytologist 167:787-796.

Vila-Aiub M.M., Neve P. and Powles S.B. 2009. Fitness costs associated with evolved herbicide resistance alleles in plants. New Phytologist 184:751-767.

Vila-Aiub M.M., Neve P., Steadman K.J. and Powles S.B. 2005b. Ecological fitness of a multiple herbicide-resistant Lolium rigidum population: dynamics of seed germination and seedling emergence of resistant and susceptible phenotypes. Journal of Applied Ecology 42:288-298.

Weaver E.S. and Thomas G. 1986. Germination responses to temperature of atrazine - resistant and - susceptible biotypes of two pigweed (Amaranthus) species. Weed Science 34: 865-870.

Winn A.A. 1988. Ecological and evolutionary consequences of seed size in Prunella vulgaris. Ecology 69:1537-1544.

Received: March 3rd, 2014

Accepted: July 2nd, 2014 